\title{
Model of Language Competence Upgrading Program for English Teachers in Indonesia
}

\author{
Him'mawan Adi Nugroho \\ English Department \\ Universitas Negeri Surabaya \\ Surabaya, Indonesia \\ himmawannugroho@unesa.ac.id
}

\begin{abstract}
This paper aims at proposing a concept in maintaining English language teachers' language proficiency as an inseparable part of their professionalism. Reviewing several previous researches dealing with English language teaching and English teachers' professional development is the method used in this paper. It leads to a concept of the language competence upgrading program due to the fact that until today the EFL (English as Foreign Language) teachers' language competence are still considered low and also many of the professional development program give a small proportion toward the language competence of the EFL teachers. The model is a 2-day upgrading program covering the practices and exercises in the four language skills, listening, speaking, reading and writing. It has specific materials for each of the skills. The information on how ICT can be used for the improvement and practice of the language skills. The impact is to give assurance that a professional English teacher should be able to show the enhancement of teachers' teaching knowledge and skills, especially in English language proficiency skills. The end result the teachers' effort is their achievement of goals and students' better performance.
\end{abstract}

Keywords-Professional Development, English language teacher, Language competence

\section{INTRODUCTION}

The vivid challenge of the 21 st century and globalization era which give impact not only on the social and cultural areas but also in education. One of the education areas concerns with teachers' quality. In a sense of pedagogical and professional competencies, English teachers often receive criticism in terms of their English language skills and in their capacity in developing teaching-learning materials for their classes [11]. Therefore, teachers particularly English teachers, need to accommodate themselves by keeping their teaching quality high. Joining professional development program surely will be able to help them to stay a breast with the challenges. The role of government or institutions in providing program for teachers' professional development is needed. Goh [5] adds that teacher educators should continue to help teachers-to-be and practicing teachers hone the craft of teaching English and develop greater professional capital by being a versatile practitioner with a strong knowledge and skills base. Indonesian recent policies clearly show that they give special concern to the quality of teachers as educators in improving the quality of national education in Indonesia. A competent teacher will be able to create an effective learning environment and manage their classes more so students' study results are on the optimum stage [14].

It is very important for the teachers to keep on upgrading their abilities since the demand and the challenges in the field of teaching are also changing. The condition is also relevant for teachers of English as foreign language. Its importance as an international language and its fast and vast growing of changes and innovations urge the English teachers to keep themselves updated. Al-Asmari [1] mentions that an English language teacher needs to manage classroom activities effectively and to have a good deal of knowledge and comprehension of many factors and variables that control and govern the process of learning and teaching in the classroom situation. The English teachers' awareness to see and realize their professional development as their inseparable part of their career process will lead to their commitment to get actively involved in the programs. Karaaslan [8] underliners the need to develop professionally as English language teachers necessitates an active engagement in the learning process in which numerous development activities for English language teachers have become handy for the purpose of self-development.

\section{A. Efl Teachers' Language Competence}

English as foreign language (EFL) teachers are the source of information and model for the students in their process of learning the target language. As non-native English speakers themselves, English language teachers still need to be able to teach the target language well. Bailey [2] and Kamhi-Stein [7] raise the issue on how much a language does one need to know to be able to teach it effectively and how does proficiency in a language interact with other aspects of teaching. The issue is related with the teachers' language competencies. Richard [12] states the competencies include the ability to provide good language models, to maintain use of the target language in the classroom, to give correct feedback on learner language, and to provide input at an appropriate level of difficulty.

Learners need and have the tendency to look up to their teachers as their model in the process of acquiring the target language. There is a very small chance that the students will get the exposure and the experience to communicate with native speakers of English. As for the chances to see and watch the use of the target language, the students can make use of the advancement of the technology to help them. The availability 
of internet access whether it is a public or a personal internet access will make the students can easily get the information using their gadgets or laptops. Therefore, the language competence of the EFL teachers is very important. It shows the teachers' full understanding and practice not only the knowledge of the target language to be used in an appropriate situation but also how to teach the target language. Language competence is best developed in the context of activities or tasks where the language is used for real purposes, in other words, in practical applications.

\section{B. Current Upgrading Program}

The current upgrading program or the popular term is inservice teacher training, particularly for English teachers, at the provincial level did not work well [13]. The program is mostly focused on how English teachers can adapt and understand the new curriculum. How the English teachers will be able to make a good lesson plan to be used in their classes. It does not mean that such program is not important, but the attention toward the teachers' language competence also need the same proportion of attention. There has never been or maybe very scarcely done a training or upgrading program which focuses on refreshing and updating English teachers' knowledge and skills on their language competence.

The most common training program for teachers including English teachers is Pendidikan dan Latihan Profesi Guru (PLPG) or teacher professional training which the latest one was held in 2016. This training is a part of certification program for teachers. In this training program the materials are mostly related with the socialization of the new curriculum and its application in the teaching and learning process and pedagogical practices. The materials on the upgrading of language competence are very little. From about 10 days training, the materials related with language skills only covers 2 days.

Even if there is a training program especially for the English teachers' language competence, mostly it was done if it is not by the school, which mostly are private schools, or by private institutions or organization, like IALF, RELC Singapore and USAID. And this kind of program is not a routine program and it is specifically for a certain group of teachers and certain schools. Based on my experience in teaching EFL teachers in PLPG program and informal interview with several teachers, I found that they need a program to refresh their knowledge especially for their language competence.

There is actually MGMP or The Subject Teacher Forum which is a nonstructural organization of teachers whose establishment was stimulated in the government Regulation No.38 in 1994 regarding Educational Personnel. It is a professional forum for subject teachers at the district level. The objectives of the organization are to develop, improve, and update teachers' knowledge and skills, to give a chance for teachers to share their experiences or best practices in teaching and how to solve teaching problems and to collaborate with other institutions or even universities for the improvement of the teaching and learning process in their classes. Supriatna [13] states that most of the MGMP or The Subject Teacher
Forum fails in meeting the objective of the organization due to some factors, such as the program does not match with the teachers' need so it is not beneficial for the teachers, the classic problem dealing with transportation problem, and lack of support from the schools' principals.

It can be concluded from the information above that the Indonesian EFL teachers face several issues first, they are lack of trainings or workshops related with their language competence, second, the unsupportive schools principals or leaderships to send teachers to the upgrading programs and third, the ineffective work of MGMP or the subject teacher forum.

\section{LANGUAge COMPETENCE UPGRAding PROGRAM FOR EFL TEACHERS}

\section{A. The Ideal Upgrading or Professional Development Program}

The attention on the English language teachers' professional development programs has to be progressed and done on the base of approach which are related to the English teachers' realities. These kind of programs should meet with teachers' needs, be based upon their day to day teaching activities, and account for teachers as learners of their teaching. Borg [3] mentions some features of a successful and ideal program such as it is based on a need analysis, it involves and collaborates with the teachers for the program materials and process, it has support from the school leadership, it has continuing support for teachers, and it is in line with teachers' experience, context and received knowledge.

Previous researches have demonstrated positive results of Continuous Professional Development (CPD) on the teachers' practice of teaching and learning and proven that CPD can contribute positively on educational processes and outcomes as in [9]; [1]; [5] and [4]. It is therefore the need of a program specifically design for the refreshing and updating English teachers' knowledge and skills on their language competence is very crucial.

\section{B. Model of Language Competence Upgrading Program For EFL Teachers}

Based on the issues faced by the EFL teachers in their effort to keep up or to upgrade their language competence, it leaves us with no other choice then to give them a model of language competence upgrading program. The model of the upgrading program is in the form of 2-day program. It covers only the practices and exercises of the four language skills, listening, speaking, reading and writing. The objectives of the program are to develop fluent and accurate written and spoken skill, to enhance the skills of listening, speaking, reading and writing, to build the notion the teacher is the model for the students in acquiring the target language, and to build awareness of the importance of becoming autonomous and creative teachers. The program uses the communicative language teaching method [10]. The activities of the suggested model of the program can be seen in Table 1 . 
TABLE I. The Model of LANGUAGe COMPETENCE UPGRAding PROGRAM

\begin{tabular}{|c|c|}
\hline$\overline{\text { DAY } 1}$ & $\overline{\text { DAY } 2}$ \\
\hline $\begin{array}{l}\text { - Listening } \\
\text { - Listening for main ideas and } \\
\text { details of straight forward } \\
\text { factual information in } \\
\text { speech } \\
\text { - Listening for main points of } \\
\text { spoken interactions and } \\
\text { discussion }\end{array}$ & $\begin{aligned}- & \text { Reading } \\
- & \text { Scanning and Skimming } \\
- & \text { Reading for main ideas and } \\
& \text { details } \\
- & \text { Reading aloud }\end{aligned}$ \\
\hline $\begin{aligned} & \text { - Speaking } \\
& \text { - } \text { Pronunciation Practice } \\
& \text { - } \text { Classroom Discourse (clear } \\
& \text { instruction focus) } \\
& \text { - } \text { Speaking Practice }\end{aligned}$ & $\begin{array}{l}\text { - Writing } \\
\text { - Write and express opinions } \\
\text { in online correspondence } \\
\text { - Write a variety of essays, } \\
\text { such as problem solving } \\
\text { essay, cause and effect } \\
\text { essay, argumentative essay } \\
\text { etc. } \\
\text { - Write summary of spoken } \\
\text { and written text }\end{array}$ \\
\hline $\begin{array}{l}\text { - The use of ICT for developing } \\
\text { and improving the listening and } \\
\text { speaking skills }\end{array}$ & $\begin{array}{l}\text { - The use of ICT for developing } \\
\text { and improving the reading and } \\
\text { writing skills }\end{array}$ \\
\hline
\end{tabular}

The main focus of the program is to give EFL teachers a chance to recharge or to upgrade their English language competence. Supriatna [13] states that the teachers need refreshment of their knowledge and skills to improve their performance.

The materials of the program are flexible. They depend on the result of the need analysis prior to the program's activities. The main interest of the program is to facilitate the EFL teachers' need of the training concerning with their language competence as much as possible. The flexibility of the program's materials is also based on the fact that there is a possibility of different needs between EFL teachers in urban and suburban areas. One of key success of a professional development program is meeting the teachers' need [16].

This concept of language upgrading program can be initiated from a school-university linkage. The idea can come from the school or teachers or the MGMP (the subject teacher forum) who see the need of such program in order to promote teacher professional development, to improve the individual teacher teaching performance, to broaden the horizon on learning and teaching and to enhance teachers' teaching knowledge and skills [15]. The university, in this case English department, can then follow up by holding the program. It can become the English department's lecturer community service program. To overcome with the problem of unsupportive leadership or school principals, the English department can cooperate with district or provincial office of education to "force" the school principals to allow their English teachers to join the upgrading program.

\section{CONCLUSION}

The study posed a model of a professional development program which specifically would help the English teachers upgrade and maintain their English proficiency. Having a good mastery of English proficiency would help the English teachers' efficacy in English language teaching. Providing EFL teachers with suitable and in accordance to their need of a professional development or upgrading program is urgently needed, especially program for EFL teachers' language competence. The language competence upgrading program can go side by side with the existing program on the implementation of curriculum and pedagogical practices. One does not have to be a native-like speakers when he or she wants to become an English teacher. The important thing is that how an English teacher to be can grasp and acquire the knowledge of the language and how to teach it properly.

\section{ACKNOWLEDGEMENT}

The writer would like to show his gratitude to Prof. Dr. Nur Mukminatien, M.Pd. from Universitas Negeri Malang who provided insights for the paper. He also thanks his 3 anonymous friends from the graduate program at Universitas Negeri Malang for the comments on the earlier version of this paper. The writer would also like to thank BUDI-DN schoolarship program as the sponsor of the writer's study at Universitas Negeri Malang.

\section{REFERENCES}

[1] Al-Asmari, A. R.. Continuous Professional Development of English Language Teachers: Perception and Practices. Advances in Language and Literary Studies vol. 7, no.3, 2016, pp. 117-124.

[2] Bailey, K. M.. Language teacher supervision: A case-based approach. New York: Cambridge University Press. 2006

[3] Borg, S.. Overview - Beyond the workshop: CPD for English language teachers. In Borg, S. (Eds.) Professional development for English language teachers: perspectives from higher education in Turkey, 2015, pp. 5-13.

[4] Giraldo, F.. The impact of a professional development program on English language teachers' classroom performance. PROFILE Issues in Teachers' Professional Development, vol. 16, no. 1, 2014, pp. 63-76.

[5] Goh, Christine C.M.. Globalization And Teacher Development For Spoken English Instruction. Indonesian Journal of Applied Linguistics, vol. 3 , no. 1, 2013, pp. 29-38.

[6] Graddol, David.. The Future of English. The British Council. 2000.

[7] Khamhi-Stein, L. D.. Teacher preparation and nonnative Englishspeaking educators. In A. Burns \& J. C Richards (Eds.), The Cambridge guide to second language teacher education (pp. 91-101). Cambridge: Cambridge University Press. 2009.

[8] Karaaslan, A.D.. Teachers' perceptions of self-initiated professional development: A case study on Bakent University English Language teachers. Unpublished master thesis submitted at Middle East Technical University. 2003. Retrieved from https://etd.lib.metu.edu.tr/upload/1217736/index.pdf

[9] Kerka, S.. Does adult educator professional development make a difference: Myths and realities. Washington: ERIC Publications. 2003.

[10] Larsen-Freeman, D.. Techniques and Principles in Language Teaching. Oxford University Press. 2000.

[11] Lengkanawati, N.S., Setyarini, S., Sari, R. D. K. \& Moecharam, N. Y.. In House Training (Iht) Model To Improve The Abilities Of English Teachers In Developing Teaching Materials. Indonesian Journal of Applied Linguistics, vol. 5, no. 1, 2015, pp. 37-43.

[12] Richards, J. C.. Exploring teacher competence in language teaching. The Language Teacher, vol. 34, no. 4, 2011, pp. 3-7.

[13] Supriatna, A.. Indonesia's Issues and Challenges on Teacher Professional Development. CICE Series, vol. 4, no. 2, 2011, pp. 29-42.

[14] Usman, M.U.. Menjadi Guru Professional: Edisi Kedua. Bandung: PT Remaja Rosdakarya. 2011. 
[15] Widodo, S.. Professional Development Programs for Teachers of English. JURNAL ILMU PENDIDIKAN, vol. 11, no. 3, 2004, pp 1-10.
[16] Wilde, J.. Assessment Strategies for Profesional Development Activities, 1996. (Online), file://c: my documents professional development key features.htm. Accessed on May 5, 2017. 